\title{
バレイショの加工特性と 品種および比重との関係
}

\author{
佐藤広顕 ${ }^{* 1} \cdot 山$ 﨑雅夫*2 ・高野克已*1
}

\section{Correlations of processing characteristics with variety and specific gravities of potatoes (Studies of Processing Characteristics of Potatoes Part 7)}

\author{
SATO Hiroaki*1, YAMAZAKI Masao*2 and TAKANO Katsumi*1 \\ * 1 Department of Applied Biology and Chemistry, Faculty of Applied Bio-science, Tokyo University of Agriculture \\ 1-1-1, Sakuragaoka, Setagaya-ku, Tokyo 156-8502
}

* 2 Department of Food Science and Technology, Faculty of Applied Bioindustry, Tokyo University of Agriculture 196, Yasaka, Abashiri-shi, Hokkaido 099-2493

The differences in texture parameters between fresh and steamed potatoes of two defferent varieties, Mayqueen and Danshaku imo, which are the two main varieties of potatoes produced in Japan were examined. Fresh samples of both varieties showed increases in hardness, cohesiveness and gumminess with increasing specific gravity. Steamed samples of both varieties showed decreses in all texture parameters with incresing specific gravity. A primary regression equation was computed to express the relationship between specific gravity and texture parameter. Samples of both varieties with identical specific gravities showed high binding strengths. Mayqueen showed a high viscoelasticity and a high resisitance to collapse. However, Mayqueen also showed a texture similar to that of Danshaku imo white using high-density potato samples, which showed no resistance. Potato thermal analysis of fresh potato samples showed a low density and a high heat capacity peak of the cell wall component in both varieties at $70 \sim 100^{\circ} \mathrm{C}$. This indicates that a large amount of heat is necessary to change the properties of hypobaric samples of both varieties by steaming. It was surmised that the properties of Mayqueen being highly mucilaginous and having a high binding strength are the main reason a large amount of heat is necessary to change the physical properties of this variety by steaming.

(Received Mar. 25, 2005 ; Accepted May 18, 2005)

バレイショは, 蒸熱時の挙動から煮崩れしやすく, マ ッシュポテト原料に適している粉質系と, 者物用に適し ている煮崩れしにくい粘質系に経験的に大別され，それ らの加工特性は大きく異なる。このようにバレイショの 加工特性に対し, 蒸熱時のテクスチャーが大きく関与す る $^{1) \sim 10)}$ 。

しかし，粉質系の男爵薯においても品温が低下すると 煮崩れしにくくなり，マッシュ時に細胞が破壊されてマ

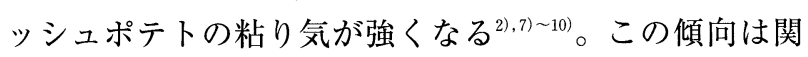
東以西で生産されたバレイショで大きいことが知られて いる。また，メークインなどの粘質系の品種でも, 北海 道産のものでは煮崩れしやすいものもある。このように, バレイショにおける粉質系と粘質系の区別ならびに加工
特性の差異は，単に品種的特徴だけでは説明できない。 筆者らは, 関東以西で生産されたバレイショが北海道 産に比べて比重が低いことに着目し，低比重（1.052） および高比重（1.094）の男爵薯を用いて, 両者の加工 特性の差異を比較・検討した。その結果, 低比重バレイ ショは高比重に比べ蒸熱による軟化が小さく, 細胞間の 結着力が強く, 粘質的性状を示すことを明らかにすると ともに, 品種だけでなく, 比重がバレイショの加工特性 に大きく影響していることを見い出した1)。

そこで本報では, 各比重の粉質系の男爵薯と粘質系の メークインについて, 生鮮時およびバレイショの加工特 性に大きく関与する蒸熱時のテクスチャーおよび熱的挙 動を比較・検討し, 品種および比重と加工特性について

$\dagger \quad$ バレイショの加工特性に関する研究（第 7 報）（前報 文献 $1,2,3,4,5,6$ )

* 1 東京農業大学応用生物科学部生物応用化学科（

E-mail : 佐藤広顕 ; hsato@nodai.ac.jp, 高野克己; takano@nodai.ac.jp

*2 東京農業大学生物産業学部食品科学科（テ $099-2493$ 北海道網走市八坂196）

E-mail :m-yamaza@bioindustry.nodai.ac.jp 
若干の知見を得たので報告する。

\section{試料および実験方法}

\section{1. 供試試料および比重の測定}

実験には2000～2003年に生産された男爵著およびメー クインを用い，それらの産地および比重をTable 1 に示 した。各比重の試料10個を選別して実験に供した。

比重は，ポテトゲージ（旭計量機, $\mathrm{DPG}-0.3 \mathrm{~K}$ ) に て測定した。永田らの算出法 ${ }^{11)} に$ 従い比重よりデンプン 含有率（\%）を算出した。

\section{2. 試料の整形およびテクスチャーの測定 ${ }^{1}$}

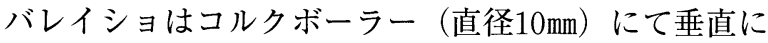
円柱状に打ち抜き，皮層を除いた髄部を長さ $10 \mathrm{~mm}$ に切断 した。蒸熱は電気蒸し器（東芝製， $\mathrm{AFC}-288$ ）にて20 分間行った。

テクスチャーは, レオナー（山電製， RE-3305）に て各比重20個の試料について測定を行った。クリアラン スを生鮮試料では $9.2 \mathrm{~mm}$, 蒸熱試料では $8.0 \mathrm{~mm}$ とし, 直径 $30 \mathrm{~mm}$ のプランジャーにより測定速度 $0.5 \mathrm{~mm} /$ 秒で，硬さ， 凝集性およびガム性を測定した。

なお, 蒸熱後の試料は恒温装置内にて, $25^{\circ} \mathrm{C} の$ 温度に 保ち測定を行った。

\section{3. 示差熱分析 ${ }^{6}$}

示差走査熱量計(セイコー電子工業製, DSC 100：DSC と略す）を用い, 昇温速度 : $1.5^{\circ} \mathrm{C} / \mathrm{min}$, 測定温度域： 30 $100^{\circ} \mathrm{C}$ ，セル：アルミニウム製シールセル，リファ レンス：蒸留水にて測定を行った。

\section{結果}

\section{1. 男爵薯およびメークインの生鮮時におけるテクスヂ ヤーと比重の関係}

Fig.1に示したように，両品種共に比重が大きくなる に従い，硬さ，凝集性およびガム性の各テクスチャー値 も増大した。そこで，それぞれのテクスチャー值と比重 の関係について回帰分析を行った。

（1）硬さ 本実験で用いた比重の範囲では，寄与 率 $=0.8282$ (男爵薯)，0.8243（メークイン）において， 両品種共に比重と硬さの間には, Fig. 1 aに示した各回 帰直線が得られた。両品種の比重1.050 (以後低比重と 記す）ならびに比重1.090（以後高比重と記す）の試料 の硬さを比較すると低比重間では $19 \%$ ，高比重間では $21 \%$ 差がみられたので, 両品種間の回帰係数の差につ いて検定 ${ }^{12)}$ した。その結果, 両側確率 $0.05 て ゙$ 両回帰係数 に有意差は認められず，同一の比重ではメークインは男

Table 1 Sources and properties of potato samples

\begin{tabular}{|c|c|c|c|c|c|}
\hline \multicolumn{3}{|c|}{ Danshaku imo } & \multicolumn{3}{|c|}{ Mayqueen } \\
\hline Sp. gravity & Locality & $\begin{array}{c}\text { Starch content } \\
(\%)\end{array}$ & Sp. gravity & Locality & $\begin{array}{c}\text { Starch content } \\
(\%)\end{array}$ \\
\hline 1.050 & Nagasaki & 7.4 & 1.047 & Nagasaki & 6.8 \\
\hline 1.052 & Hokkaido & 7.8 & 1.048 & Nagasaki & 7.0 \\
\hline 1.054 & Nagasaki & 8.3 & 1.049 & Nagasaki & 7.2 \\
\hline 1.056 & Hokkaido & 8.7 & 1.051 & Hokkaido & 7.6 \\
\hline 1.059 & Hokkaido & 9.3 & 1.053 & Chiba & 8.1 \\
\hline 1.059 & Nagasaki & 9.3 & 1.054 & Gunma & 8.3 \\
\hline 1.060 & Kagoshima & 9.5 & 1.058 & Hokkaido & 9.1 \\
\hline 1.062 & Ibaragi & 10.0 & 1. 059 & Hokkaido & 9.3 \\
\hline 1.066 & Hokkaido & 10.8 & 1.062 & Gunma & 10.0 \\
\hline 1.070 & Gunma & 11.7 & 1.066 & Gunma & 10.8 \\
\hline 1.073 & Gunma & 12.3 & 1.067 & Hokkaido & 11.0 \\
\hline 1.074 & Hokkaido & 12.5 & 1.068 & Hokkaido & 11.2 \\
\hline 1.077 & Hokkaido & 13.2 & 1.072 & Hokkaido & 12.1 \\
\hline 1.080 & Hokkaido & 13.8 & 1.075 & Hokkaido & 12.7 \\
\hline 1.083 & Hokkaido & 14.4 & 1.079 & Hokkaido & 13.6 \\
\hline 1.083 & Hokkaido & 14.4 & 1.080 & Chiba & 13.8 \\
\hline 1.086 & Chiba & 15.1 & 1.081 & Chiba & 14.0 \\
\hline 1.089 & Chiba & 15.7 & 1.082 & Hokkaido & 14.2 \\
\hline 1.089 & Hokkaido & 15.7 & 1.083 & Hokkaido & 14.4 \\
\hline 1.091 & Gunma & 16.1 & 1.085 & Hokkaido & 14.9 \\
\hline 1.092 & Hokkaido & 16.3 & 1.087 & Hokkaido & 15.3 \\
\hline 1.094 & Hokkaido & 16.8 & 1.088 & Hokkaido & 15.5 \\
\hline 1.095 & Hokkaido & 17.0 & 1.089 & Hokkaido & 15.7 \\
\hline 1.098 & Hokkaido & 17.6 & 1.090 & Hokkaido & 15.9 \\
\hline
\end{tabular}


爵薯に比べて硬さが約 $20 \%$ 高いことが統計的に明らかに なった。

（2）凝集性 寄与. 率 $=0.7941$ (男 爵 薯)，0.7774 (メークイン) において，両品種共に比重と凝集性の間 には，Fig. 1 bに示した各回帰直線が得られた。両品種 では，低比重間および高比重間における凝集性の差は $0.4 \%$ と硬さに比べると小さかった。しかし，凝集性は 測定值自体が 0 〜 の範囲であり，他のテクスチャー値 に比べ数值の差が縮小される。そこで，両品種間の回帰 係数の差について検定したところ，両側確率 0.05 で両回 帰係数に有意差は認められず，比重の大小に関係なくメ ークインは男爵薯に比べて凝集性が約 $4 \%$ 小さくなるこ とが統計的に明らかになった。

（３）ガム性 ガム性は硬さと凝集性の積であり, 硬 さ，凝集性と同様に比重と正の相関を示した。メークイ ンは男爵薯に比べて，同一比重でガム性が16～28\%大き な值を示した。寄与率 $=0.7936$ (男爵薯)，0.7856（メ ークイン) において，両品種共に比重とガム性の間には Fig. 1 cに示した各回帰直線が得られた。両品種の低比
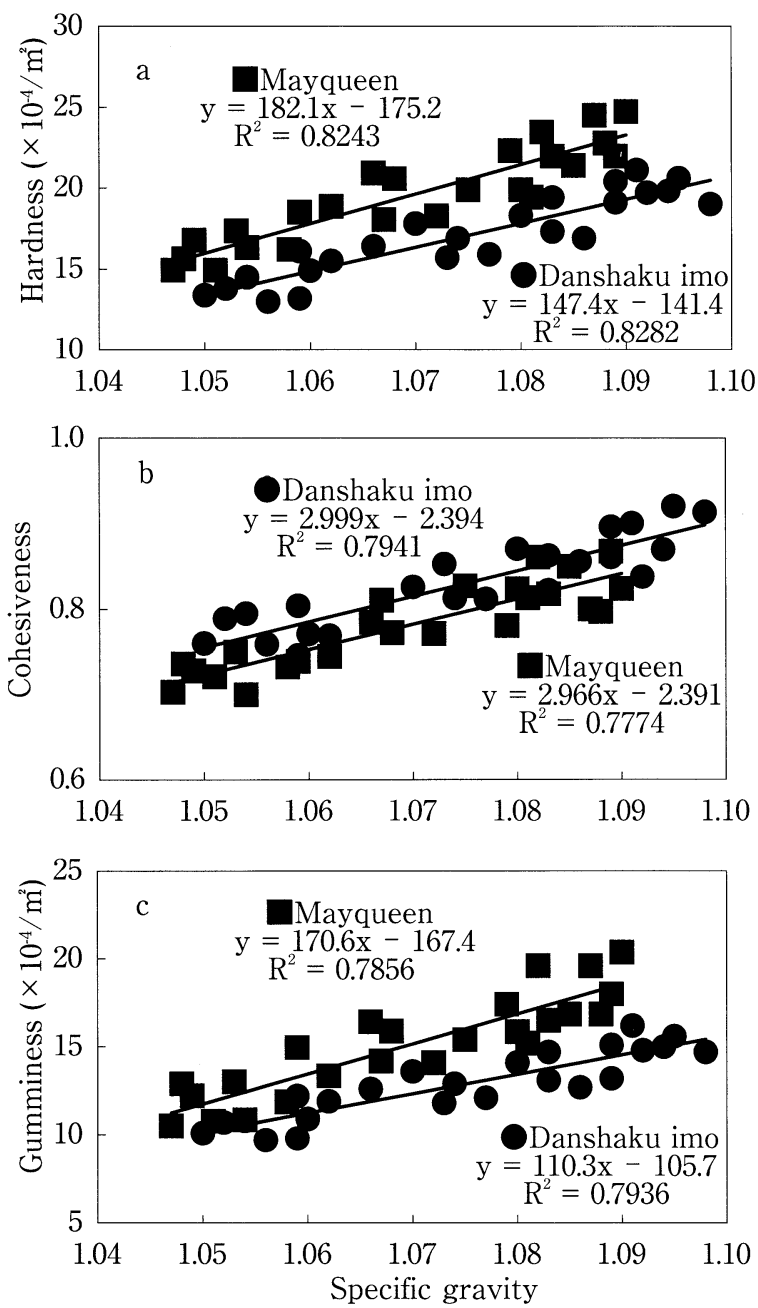

Fig. 1 Correlations between specific gravity and texture parameters of fresh potatoes of different varieties
重間および高比重間のガム性の值にはそれぞれ $16 \%$ よお び28\%の差がみられたので, 両品種間の回帰係数の差に ついて検定した。その結果, 両側確率 0.05 で両回㷌係数 に有意差が認められ，男爵薯とメークインではガム性の 変化量が比重により差があり，メークインは男爵薯に比 べ高比重ほどガム性の值が大きくなることが明らかにな った。

2. 男爵薯およびメークインの蒸熱後におけるテクスチ ヤーと比重の関係

Fig. 2に示したように，両品種共に比重の増加に従い, 蒸熱後のいずれのテクスチャー值も生鮮時と異なり低下 した。そこで, 品種間におけるテクスチャーの相違を比 較するため，それぞれ比重と各テクスチャー值について 回帰分析を行った。

（1）硬さ 本実験で用いた比重範囲において，メ ークインは男爵薯に比べて，同一比重で硬さが約 3.5 $6.0 \%$ 小さな值を示した。寄与率 $=0.7976$ (男爵薯), 0.7793 (メークイン) において, 両品種共に比重と硬さ の間には，Fig.2 aに示した各回帰直線が得られた。両
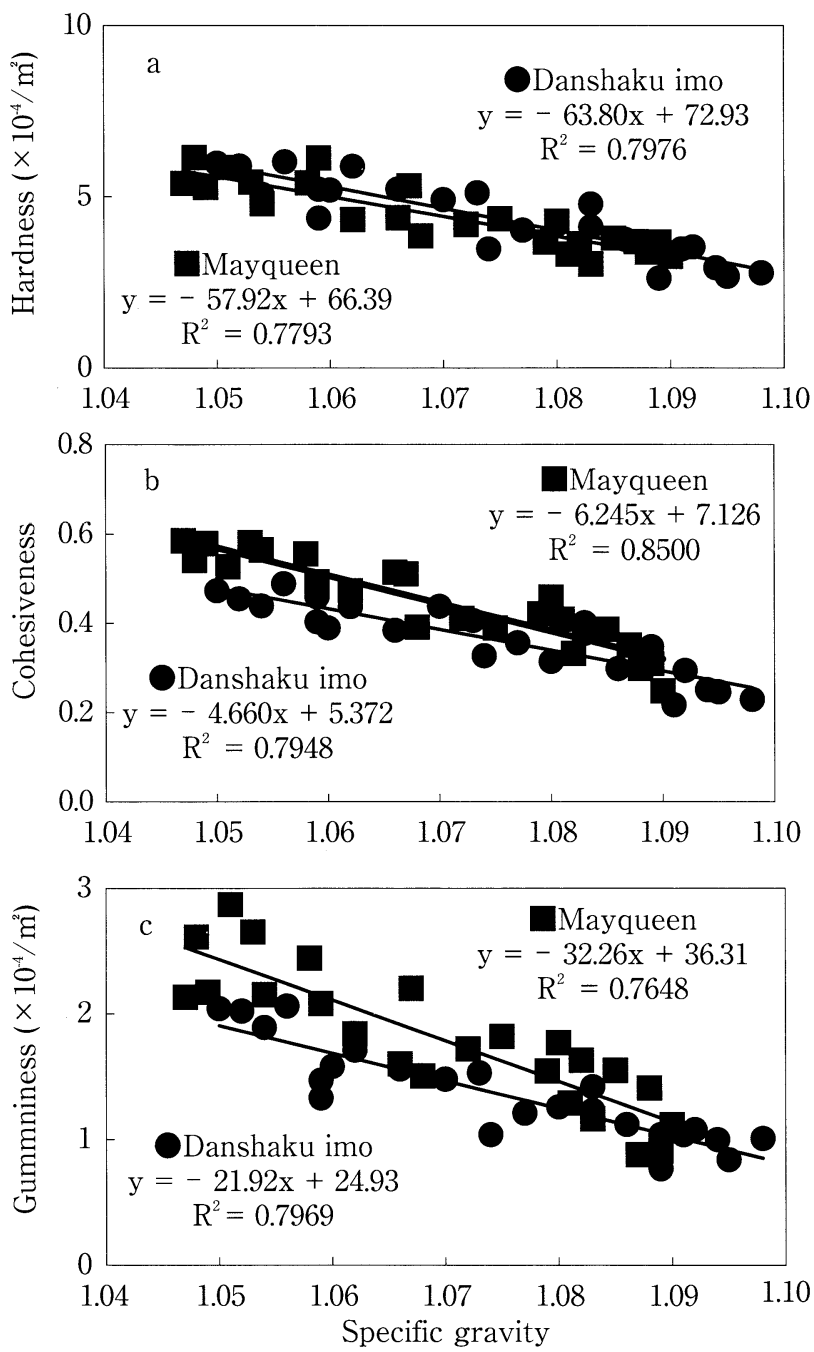

Fig. 2 Correlations between specific gravity and texture parameters of steamed potatoes of different varieties 
品種の硬さの值を比較すると低比重間では $6 \%$, 高比重 間では $4 \%$ 差がみられたので，両品種間の回帰係数の 差について検定した。その結果，両側確率0.05で両回帰 係数に有意差は認められず，比重の大小に関係なくメー クインは男爵薯に比べて蒸熱後の硬さは $5 \%$ 小さな值を 示すことが明らかになった。

（2）凝集性 メークインは男爵薯に比べて, 同一比 重で凝集性が 9 〜 19\%大きな值を示した。寄与率= 0.7948 (男爵薯)，0.8500（メークイン）において，両 品種共に比重と凝集性の間には，Fig. 2 bに示した各回 帰直線が得られた。両品種の凝集性の值を比較すると低 比重間で $19 \%$ ，高比重間で $9 \%$ 差がみられたので，両 品種間の回帰係数の差について検定した。その結果，両 側確率 0.05 で両回帰係数に有意差が認められ, 男爵薯と メークインは比重によって凝集性の值の変化量に差があ り，メークインは男爵薯に比べ比重が大きくなるほど結 着性の低下率が大きいことが明らかになった。

（３）ガム性 メークインは男爵薯に比べて, 同一比 重でガム性が11〜28\%大きな值を示した。寄与率= 0.7969 (男爵薯)，0.7648（メークイン）において，両 品種共に比重とガム性の間に，Fig. 2 cに示した各回帰 直線が得られた。両品種の值を比較すると低比重間で $28 \%$ ，高比重間で $11 \%$ 差がみられたので，両品種間の 回帰係数の差について検定した。その結果, 両側確率0.05 で両回帰係数に有意差が認められ，男爵薯とメークイン ではガム性の変化量が比重により差があり，メークイン は男爵薯に比べ高比重ほどガム性の值が小さくなること が明らかになった。

\section{3. 低比重および高比重の男爵薯およびメークインの熱} 挙動について

男爵薯（比重1.054, 比重1.092），メークイン（比重 1.049，比重1.087）を用いてDSCによる熱分析を行った。 Fig. 3に示したように，両品種共 $60 \sim 70^{\circ} \mathrm{C}$ およ゙ $70 〜 100$

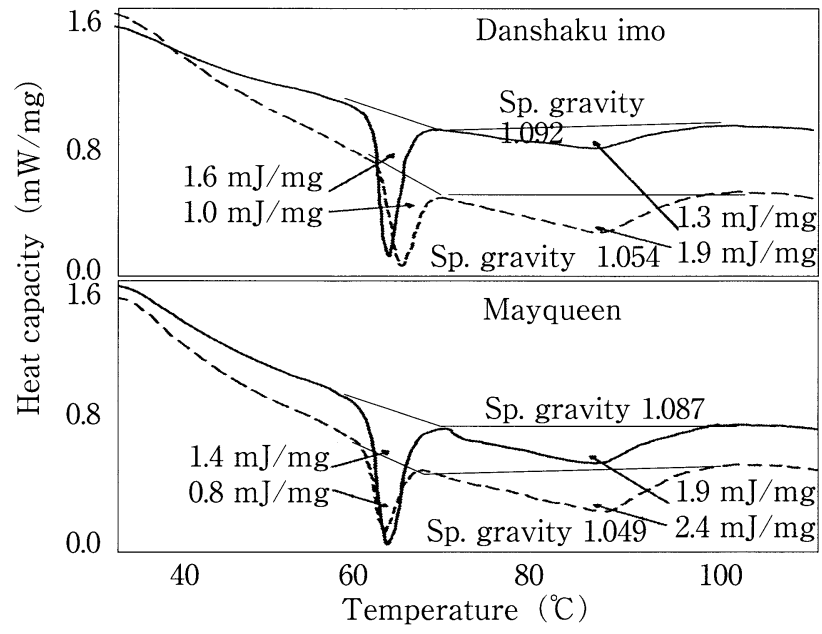

Fig. 3 Comparison of change in heat capacity with temperature of potatoes of different varieties and specific gravities
${ }^{\circ} \mathrm{C}$ に吸熱ピークが検出された。バレイショ $1 \mathrm{mg}$ あたの 総吸熱量は男爵薯では $2.9 \mathrm{~mJ}$, メークインでは 3.2 $3.3 \mathrm{~mJ}$ を示し, 両品種共に高比重と低比重間では吸熱 量に差がみられなかった。しかし，同様な比重にもかか わらず，低・高比重共に男爵薯はメークインに比べ吸熱 量が約10\%小さかった。

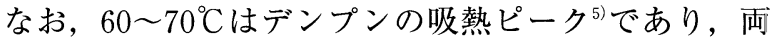
品種共に高比重試料が低比重試料に比べて大きな吸熱量 を示した。この差異はデンプン含量によるものと考えら れた。デンプン含量は男爵薯の比重1.054では8.3\%，比

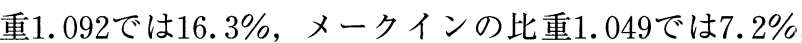
比重1.087では $15.3 \%$ あった。各試料中のデンプン 1 mgあたりの吸熱量は，いずれも $9 \sim 12 \mathrm{~mJ}$ あ゙あり, 男爵 薯とメークイン共にデンプンの吸熱量は比重によって大 きな差はみられなかった。

70〜 $100^{\circ} \mathrm{C}$ の吸熱ピークは，前報6)で報告したように細 胞壁成分に由来する。同吸熱量はバレイショの総吸熱量 に対し，男爵薯の高比重試料で $45 \%$, 低比重試料で $66 \%$, 一方メークインの高比重試料で $58 \%$ ，低比重試料で $75 \%$ を占めた。バレイショの固形分に占める細胞壁成分は約 $7 \%(1), 3)$-6゙あるにもかかわらず，これらの成分の熱挙 動に多くの熱量を要することが明らかになった。両品種 共, 蒸熱による各テクスチャー值の変化量の小さな低比 重試料が高比重試料に比べて，また，粘質系のメークイ

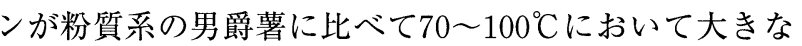
吸熱量を示した。

\section{考察}

大谷 ${ }^{13) \sim 15}$ は，男爵薯およびメークインのテクスチャー の相違は，ペクチン，へミセルロースおよびセルロース の構成比やその構造の差によるとし，メークインは男爵 薯に比べセルロースが多く細胞自体が強靫であると推論 している。今回の結果もそれを裏付けるように，メーク インは男爵薯に比べ硬く，粘弾性の大きなテクスチャー を示した。筆者らも男爵薯を用いて同一品種での比重差 によるテクスチャーの相違を検討した際, 生鮮時では硬 く, 組織の強固 ${ }^{1}$ だった高比重の男爵薯ほどセルロース 含量が多かっだ)。以上のことを考え合わせると，バレ イショでは粘質系は粉質系に比べ，また，同一品種では 比重の大きなものほど，細胞壁成分であるセルロースの 含量が多く, 強固なテクスチャーを示すと推察される。

さらに筆者らは, 男爵薯において, 高比重のものほど 結着力の弱い水溶性のペクチンが多く2) 4), また蒸熱処 理によるペクチンの水溶化率が大き( ${ }^{2)}$ (4)ので，細胞間 の結着力が大きく低下して分離性が増大し, 軟らかく崩

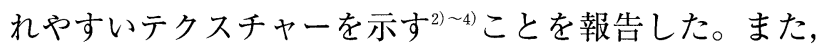
大谷 ${ }^{13) ~ 15)}$ も煮崩れしやすい男爵薯では水溶性のペクチン が多いのに対し，煮崩れしにくいメークインではエステ ル化度の小さな流動性の少ないぺクチンやへミセルロー スの割合が多くなると報告している。 
筆者ら ${ }^{6)}$ は, 男爵薯の細胞壁成分においてもその主体 を成すセルロース画分の量や吸熱量が低比重試料が多く, 細胞壁成分の状態変化には低比重試料ほど多くの熱量が 必要なことを報告している。今回, 品種間や比重差によ って蒸熱処理後のテクスチャーが異なったのは上記のよ うな要因が作用していると推察され，バレイショの加工 特性に対しては，細胞壁成分の熱挙動が大きく影響して いることが明らかになった。

なお，生鮮時においては，硬さおよび㠜集性で品種間 の回帰係数に有意差がみられなかったにもかかわらず， 両者の積であるガム性では有意差が認められた。これは 硬さ，凝集性の回帰係数が共にメークインが大きな值を 示したため，両者の積算值であるガム性では回帰係数の 解離が増大したためと考えられた。それに対し，蒸熱後 の各テクスチャー值ではガム性だけでなく凝集性におい ても回帰係数に有意差が認められた。これは, 両品種共 に比重の大きな試料ほど蒸熱後では蒸熱によりペクチン が水溶化し，細胞間の結合力が低下する2),4) ため，バレ イショ組織間の結合力を示す凝集性の変化量も高比重試 料で大きくなったためと考えられる。

また, 生鮮試料の熱分析の結果, 男爵薯, メークイン 共に低比重試料が高比重に比べ, 細胞壁成分に起因 ${ }^{6} す$ る吸熱量（70 $\left.100^{\circ} \mathrm{C}\right)$ が大きく，両品種共低比重試料 が蒸熱による細胞壁成分の軟化には多くの熱量が必要で あることが示唆された。さらにこの傾向は，同比重で結 着力の大きな粘質系のメークインが顕著であり，粘質系 の試料が粉質系に比べ蒸熱時の物性変化に多くの熱量が 必要であることが推察された。

今回得られた結果から, バレイショは同一品種でも比 重によりテクスチャーは大きく異なっていた。粉質系の 男爵著では低比重のものは粘質系の性質を, 粘質系のメ ークインでは高比重のものは粉質系の性質を示すことが 明らかとなり，特に，両品種共に高比重試料ではテクス チャーは非常に近似したものであった。

以上，バレイショの粉質系，粘質系の主要品種である 男爵著ならびにメークインについて, 加工特性と比重の 相違との相関を明らかにした。今後は，他の国産主要品 種についても同様の解析を行うことにより，各品種の加 工特性の詳細を明らかにすることができると考える。

\section{要 約}

日本で生産されるバレイショの主要な 2 品種において, 生鮮時ならびに蒸熱処理後におけるテクスチャーの相違 を検討した。

(1) 生鮮時では, 両品種共に比重の増加に従い, 硬さ, 凝集性扔よびガム性の各テクスチャー值は増大する 傾向を示した。両品種共にそれぞれ比重と各テクス チャー值間には一次回帰式が得られた。同一比重で はメークインが硬く, 粘弾性の大きなテクスチャー を示した。
(2) 蒸熱処理後では, 両品種共に比重の増加に従い, いずれのテクスチャー值も低下する傾向を示し，両 品種共にそれぞれ比重と各テクスチャー值間には一 次回帰式が得られた。同一比重ではメークインが結 着力が強く, 粘弾性に富んだ崩れにくいテクスチャ 一を示した。なお，メークインも高比重試料では, 男爵薯に近似した崩れやすいテクスチャーを示すこ とが明らかとなった。

(3) 生鮮試料の熱分析の結果, 両品種共に低比重が, 細胞壁成分由来の $70 \sim 100^{\circ} \mathrm{C}$ の吸熱ピークで大きな 吸熱量を示し, 両品種共低比重試料のほうが蒸熱に よる性状変化には多くの熱量が必要であることが示 唆された。さらにこの傾向は, 結着力の大きな粘質 系のメークインが顕著であり，粘質系の試料が蒸熱 時の物性変化に多くの熱量が必要であること推察さ れた。

\section{文献}

1 ）佐藤広顕 - 高野克己 - 光浦暢洋 - 谷村和八郎 - 鴨居 郁三：比重の異なるバレイショの物性について，日食 工誌，38，1134～1136（1991）

2 ）佐藤広顕 - 高野克己 - 光浦暢洋 - 谷村和八郎 - 鴨居 郁三：比重の異なるバレイショより調製したマッシュ 試料の物理的性状について, 日食工誌, 38, 1071〜1075 (1991)

3 ）佐藤広顕 - 高野克己 - 小嶋秩夫 - 谷村和八郎 - 鴨居 郁三：比重の異なるバレイショの物性に及ぼすぺクチ ン質の影響，日食保蔵誌，24，355～359（1998）

4 ）佐藤広顕・高野克己：比重の異なるバレイショの蒸 熱による物性およびペクチンの性状変化の比較, 日食 保蔵誌，26，17～21（2000）

5 ）佐藤広顕・永島俊夫・高野克己：比重の異なるバレ イショから調製したデンプンの性状, 食科工誌, 48,475 〜 481 (2001)

6 ）佐藤広顕・山崎雅夫・高野克己：低比重および高比 重バレイショにおける細胞壁多糖の組成および熱挙動 の比較解析，日食保蔵誌，31，151～154（2005）

7 ）松元文子・橋谷淳子：マッシュポテトに関する実験 (第 1 報)，家政誌，14，341～344（1963）

8 ）橋谷淳子・松元文子：マッシュポテトに関する実験 (第 2 報)，家政学，20，95～99（1969）

9 ）橋谷淳子・平野雅子・比企み上子・松元文子：マッ シュポテトに関する実験（第 3 報），家政誌，23，116 〜120 (1972)

10）今泉雅子：じゃがいもの調理, 調理科学, 18, 114 〜16 (1985)

11）農文協：畑作全書一イモ類編一（農文協, 東京), p. 127 (1981)

12）市原清志：バイオサイエンスの統計学

13）大谷貴美子：調理特性の異なるじゃがいも（Solanum 
tuberrosum）の非澱粉性多糖の構造（第 1 報）水可溶 性多糖について, 日家政誌，40，593～601（1989）

14）大谷貴美子：調理特性の異なるじゃがいも（Solanum tuberrosum）の非澱粉性多糖の構造（第 2 報）熱水お よびシュウ酸アンモニウム可溶性多糖について, 日家 政誌，42，313～320（1991）
15）大谷貴美子：調理特性の異なるじゃがいも（Solanum tuberrosum）の非澱粉性多糖の構造（第 3 報）アルカ リ可溶およびアルカリ不溶性多糖について, 日家政 誌，42，321～325（1991）

(平成 17 年 3 月 25 日受付, 平成 17 年 5 月 18 日受理) 